\title{
Economic Life Cycle of Biomass Equipment and its Renovation
}

\author{
Katarína Teplická ${ }^{1}$, Martin Kováč ${ }^{2}$, Erika Škvareková ${ }^{1}$, Andrea Seňová ${ }^{1}$ \\ ${ }^{1}$ Technical University Košice, Institute of Earth Sources, Park Komenského 19, Košice, Slovakia \\ ${ }^{2}$ Technical University Košice, Institute of Civil Engineering, Vysokoškolská 4, Košice, Slovakia
}

\begin{abstract}
The main goal of this article is to determine the optimal time period of boiler for biomass renewal, because its usage affects the financial situation of the firm in the form of costs. In this contribution is applied the method of operational research - the method of optimal time of machine renovation. The results of the analyses point to the optimal period of biomass boiler renovation before its service life in the 11th year. Operating costs are increasing about $9 \%$ after this time. By using this model there is ability to plan financial sources for buying new biomass boiler at 5500-15600€ on the market. The scientific benefit lies in the fact that the model is applicable to all types of equipment and machinery, in various industrial areas and in services and it is preventive instrument for financial planning for machine renovation.
\end{abstract}

Keywords - optimization, profit, costs, biomass, quantitative models, life cycle

\section{Introduction}

Performance of the companies depends on timely and proper decisions of management by the direction for obtaining of financial, material, personal, and technical and technology sources. Very important parts of management are decisions about work efficiency achieving for individual working places and employees in the production.

DOI: 10.18421/TEM94-13

https://doi.org/10.18421/TEM94-13

Corresponding author: Katarína Teplická,

Technical University Košice, Institute of Earth Sources,

Park Komenského 19, Košice, Slovakia

Email: katarina.teplicka@tuke.sk

Received: 21 July 2020.

Revised: 29 August 2020.

Accepted: 07 September 2020.

Published: 27 November 2020.

(cc) BY-NC-ND (C) 2020 Katarína Teplická at al; published by UIKTEN. This work is licensed under the Creative Commons Attribution-NonCommercial-NoDerivs 4.0 License.

The article is published with Open Access at www.temjournal.com
The one part of decision area is the area of operation research directed to efficiency of firm's fixed capital - equipment usage, optimal management of stocking and sales, localization of client and transport, environment [9]. In the area of process optimization, the process approach and the monitoring of individual processes in terms of efficiency play an important role [22]. Efficiency is presented in production process by using of active equipment and its operation capability [23]. Securing of fluent running of production process depends from the level of assets that means machineries and equipment. Care of machines and equipment creates high operating costs and therefore it is necessary to monitor functional state of the machinery and production equipment during the life cycle of machines. By economic view it is important to monitor physical and moral depreciation of machines, to find out ways for equipment renovation and to optimize the interval of real lifetime. Renewable energy sources are new possibilities to reducing energy consumption and operating costs. Biomass is an energy that is widely used by businesses and in households. Biomass requires equipment and machines that entails input and operating costs for the firms over their lifetime [19]. These operating costs are increasing during the lifetime of the equipment and it is necessary to look for the possibilities of equipment renovation from the economic point of view. Process of machines renovation can be realized by the quantitative models of operational research that enables managers to optimize the interval of life cycle. In this article we deal with optimization of the biomass boiler. Wiece et.al. (2020) dealt with optimizing of material costs. One of the tools is activity based costing which is groundwork for decision making process in the material supply area. On the base of ABC method a model of materials requirements planning was developed, which considers minimizing the number of different kinds and sizes of materials by using alternative materials [5].This approach is one of the rationalization areas for maintenance process of machines and it is connected with material (substitution components) that are very important for renovation of the machines. Senthill et.al. (2019) 
implemented new technique using numerical simulation of a machine - the grinder machine. The performance of this technique was compared with the conventional techniques and results were better in reducing the operating costs for the machine [21]. This information is very important for optimizing the operating costs of a machine - the biomass boiler.

\section{Literature Review}

Present management cannot run without significant use of quantitative methods of operation research during solving economic problems in care of equipment and machines. Chovanová, Bavčanová (2014) said the managers at present time are oriented to solving operational problems, which brings immediate effect for company. Traditional deterministic models of operational research are used for solving decision making problems - optimal production management, optimal stock management, creating of company information database and others [7]. Optimizing of processes in companies is base of effective decision making. On the basis of comparison of economic, financial, social, technical, environmental parameters by using quantitative methods can manager's effective decision and evaluation of the performance of the firm [6]. The economic life cycle of the equipment (Figure 1.) is three basic phases. The first phase involves the purchase and commissioning of the equipment, the second phase involves the use and operation of the equipment, and the third phase involves the decommissioning of the equipment. All three phases represent economic impacts for businesses.

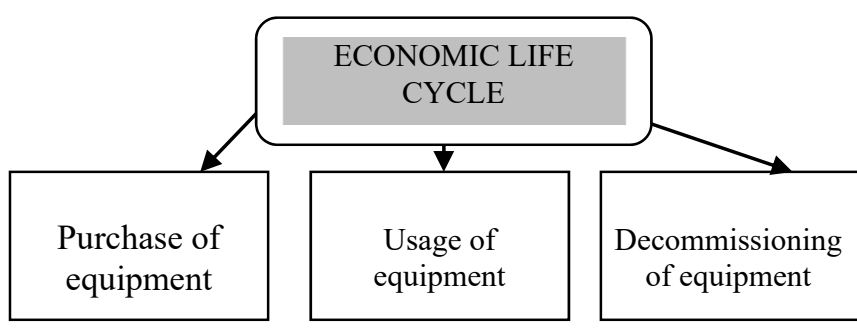

Figure 1. Economic life cycle of equipment Source: own source

The costs are rising in term of machines usage. The category of costs creates operating costs and environmental fees for energy, environmental taxes, and financial costs [1]. In a production firm, it is necessary to use production equipment that is the main production tool and its service situation is necessary assumption for securing continuous production [11]. Finance is the reason to search optimal time interval for renovation of equipment. During usage of machines the costs are raising for service, securing of repair, maintenance, insurance. The firm must minimize those costs. The financial situation of the firm is very important for the reproduction process of equipment [10]. The use of quantitative models of operation research creates a sort of solving problem of reproduction biomass boiler. Optimized model of reproduction determines the time when it is important to make reproduction [25]. Biomass is one of the possible ways of producing energy and therefore these forms of energy generation are supported by the state. Consumers and firms can benefit from state support for the installation of biomass boilers that cover the need for heat and hot water [12]. The aid concerns pellet boilers, briquettes, chips, and lump wood gasification boilers. The condition is the replacement of the coal-fired boilers. When selecting a biomass plant, it is important to evaluate the advantages and disadvantages. Consumer preferences are very important and therefore various surveys are being carried out on what the customer wants. Diamantopoulus et.al. (2012) said that the knowledge about consumers' preferences is important for many marketing decisions; therefore, marketing researchers have developed methods that measure consumer preferences [2]. Gabriel, Tschandl, Posch (2014) said energy solutions based on biomass and bio-fuels provide clean and renewable energy [17]. Zhou et.al. (2019) stated in their article that biomass can be converted into electric power through various methods. Biomass is used for facility heating, electric power generation, and combined heat and power. The biomass encompasses a large variety of materials, including wood from various sources, agricultural residues, and animal and human waste. [3]. Zgodavová et.al. (2016) said renewable energy sources as an attractive element of green-thinking industrial companies are strategic goal of Environmental policy of the EU [14]. Beer, Rybár, Kal'avský (2018) presented that the industry companies are now using green thinking utilizing biofuels to mitigate the impact their activities have on the environment by reducing the emissions of greenhouse gases [16]. Ostrowski et.al. (2017) presented that the biomass boiler is a leader in the development of boiler technology and energy management projects through sustainable solutions for renewable energy and energy efficiency by biomass. This is an instrument for decreasing energy costs [18]. Tauš et.al (2015) stated that biomass boilers as an alternative fuel solution can help reduce carbon emissions, and reduce operating and fuel costs [20]. Very important information about fuel biomass boilers and their effect is presented in Figure 2. The basic advantages of biomass boilers include high efficiency and favorable fuel price compared to gas. Biomass combustion is also considered to be more environmentally friendly than natural gas. When buying a biomass boiler from quality 
producers, the warranty period is around 5 years. The overall lifetime of biomass boilers is 20 years. The installation of these boilers is currently financially subsidized by the state, which can reduce input and operating costs.

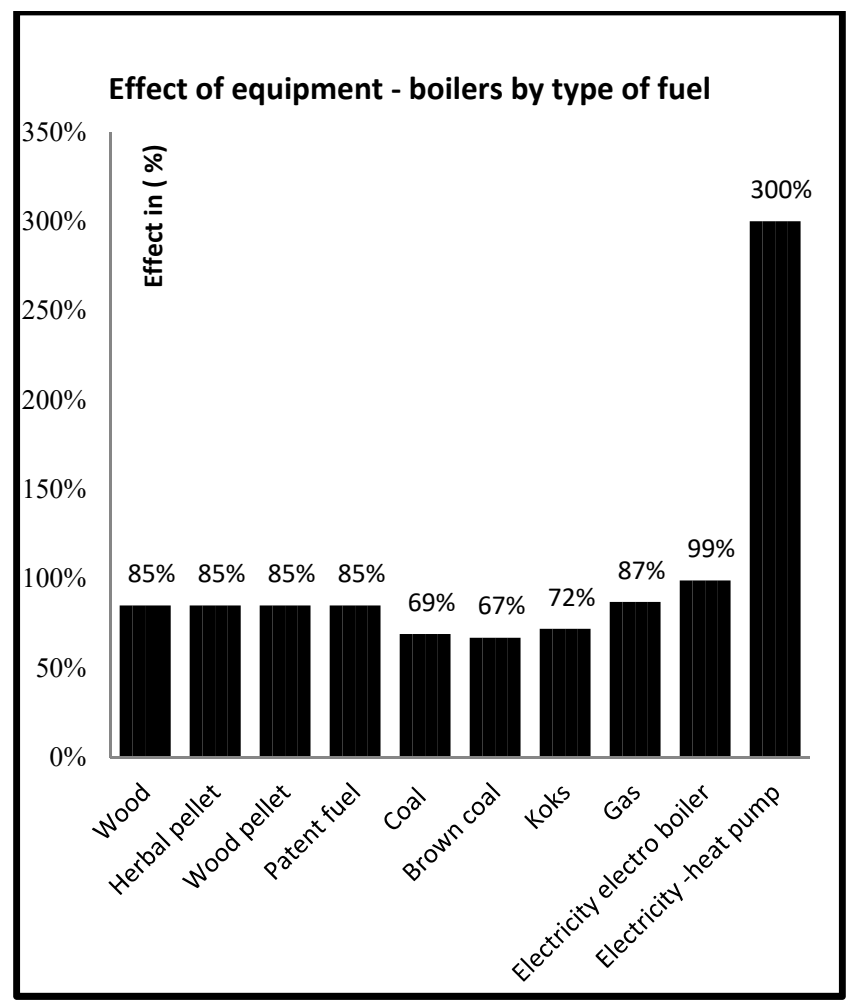

Figure 2. Percentage of biomass boilers performance Source: [13]

The disadvantage may be the need for a warehouse, respectively rooms for fuel storage and emptying the ash hopper manually, but some boilers already have an automatic ash removal function. Prior tom choosing a biomass boiler, one must consult the seller and familiarize oneself with the parameters of individual boiler models. Automatic pellet feeding, wood chips, heat exchanger cleaning, flexible storage, feeding systems, large filling areas, and long fuel proof intervals are customer requirements. The greatest comfort in using biomass boilers is to meet the requirements of the customers. Satisfaction of customer requirements is the basis for the proper functioning of processes according to ISO 9001: 2016. In the field of biomass boilers sales, it is necessary to monitor the type of fuel, consumption, fuel value and operating costs. [24]. In the area of using biomass for heating, the KPI - key performance indicators need to be monitored: high reliability, long active life, comfortable heating and hot water, independence from fuel oil or gas, lower consumption costs, economical operation of the device. The economic efficiency of biomass boilers depends on the level of operating costs and therefore it is important to analyze the risks that can arise in the use of biomass boilers. Simionescu et.al (2017) dealt with failures of machines and said that one of the most important problems of the machines is the accidental failure. Authors proposed a method to control the working without failures for any machine with maintenance interventions and this approach leads to an optimum operation [4]. This system should be implicated for biomass boiler because reducing failures brings reducing operating costs. It is very important to monitor the input material, its quality, and its quantity, for each type of biomass boiler. The basic material affects the efficiency of biomass boiler and quantity of produced energy [16]. The basic indicators of biomass boilers are presented in Table 1.

Table 1. Efficiency of biomass boiler

\begin{tabular}{|c|c|c|c|}
\hline Fuel & $\begin{array}{c}\text { Fuel } \\
\text { value }\end{array}$ & Consumption & $\begin{array}{l}\text { Costs in } \\
\text { year }(€)\end{array}$ \\
\hline Wood & $\begin{array}{c}3,89 \\
\mathrm{kWh} / \mathrm{kg}\end{array}$ & $6746 \mathrm{~kg}$ & $742 €$ \\
\hline $\begin{array}{c}\text { Herbal } \\
\text { pellet }\end{array}$ & $\begin{array}{c}4,44 \\
\mathrm{kWh} / \mathrm{kg}\end{array}$ & $5904 \mathrm{~kg}$ & $886 €$ \\
\hline $\begin{array}{l}\text { Wood } \\
\text { pellet }\end{array}$ & $5 \mathrm{kWh} / \mathrm{kg}$ & $5247 \mathrm{~kg}$ & $1259 €$ \\
\hline Patent fuel & $\begin{array}{c}4,44 \\
\mathrm{kWh} / \mathrm{kg}\end{array}$ & $5904 \mathrm{~kg}$ & $1240 €$ \\
\hline Coal & $\begin{array}{c}5,83 \\
\mathrm{kWh} / \mathrm{kg}\end{array}$ & $5541 \mathrm{~kg}$ & $1108 €$ \\
\hline $\begin{array}{c}\text { Brown } \\
\text { coal }\end{array}$ & $\begin{array}{c}4,17 \\
\mathrm{kWh} / \mathrm{kg}\end{array}$ & $7987 \mathrm{~kg}$ & $1198 €$ \\
\hline Coke & $\begin{array}{c}6,94 \\
\mathrm{kWh} / \mathrm{kg}\end{array}$ & $4460 \mathrm{~kg}$ & $1427 €$ \\
\hline Gas & $\begin{array}{c}9,60 \\
\mathrm{kWh} / \mathrm{m}^{3}\end{array}$ & $2670 \mathrm{~m}^{3}$ & $1415 €$ \\
\hline Electricity & 1 & $22525 \mathrm{kWh}$ & $2854 €$ \\
\hline Electricity & 1 & $7433 \mathrm{kwh}$ & $818 €$ \\
\hline
\end{tabular}

Source: [13]

\section{Methodology of Research}

Quantitative models - integrated models of operational research are an important tool for optimizing production factors in companies mean in an enterprise, and they are tools for decision-making, serving for competitiveness increase [15]. Operation research creates a wide range of mathematical problem-solving techniques and methods, such as critical path method, simulation, dynamic programming [8]. They enable to look for the right solutions of problems in business processes and optimize all resources in the enterprise. Through quantitative models it is possible to solve problems 
with machines in the firms [13]. During problem solving that is priority for the firm in area of production equipment renovation we have solved this problem according the models used from operation analysis renovation. The basis of this model is to follow up process of production equipment wearing in sense of removing negative consequences due to the physical wearing and to follow up the volume of service cost, that are connected with securing of production equipment repair and maintenance. When managing subject should to decide about time of production equipment displacing form the production process due to its obsolescence, malfunction or high service intensity, it must apply the following decisions:

- To evaluate physical state of production equipment

- To evaluate durability of equipment in relation to the technical durability

- To evaluate level of depreciation of production equipment

- To evaluate financial possibilities for new investment

- To evaluate way for new production equipment obtaining

The theory of restoration deals with the problems of object replacement, which wear out and fail [25]. One of the optimization models is the model of the optimal device recovery time, which is applied in the contribution. Model of renovation is effective way for finding of optimal time period in which production equipment will be renewed [25].

Calculation of cumulative operating costs $\left(\mathrm{N}_{\mathrm{P}}\right)$

$$
\mathrm{N}_{\mathrm{P}}=\sum_{\mathrm{t}=1}^{\mathrm{n}}\left(\mathrm{N}_{\mathrm{pt}}+\mathrm{N}_{\mathrm{pt}+1}\right)
$$

Calculation of cumulative depreciation (Op)

$$
\mathrm{O}_{\mathrm{p}}=\mathrm{OC}-\mathrm{ZCt}
$$

Calculation of total cost of fixed capital $(\mathrm{Nc})$

$$
\mathrm{N}_{\mathrm{c}}=\mathrm{N}_{\mathrm{P}}+\mathrm{O}_{\mathrm{p}}
$$

Calculation of average total cost of fixed capital (Npr)

$$
\mathrm{N}_{\mathrm{pr}}=\frac{\mathrm{N}_{\mathrm{c}}}{\mathrm{t}}
$$

Calculation of optimal time period $\left(\mathrm{t}_{\mathrm{opt}}\right)$

$$
\mathrm{t}_{\mathrm{opt}}=\min \mathrm{N}_{\mathrm{pr}}
$$

Legend:

$\left(\mathrm{N}_{\mathrm{p}}\right)$ - cumulative operating costs, $(\mathrm{ZC})$ - residual price, $(\mathrm{t})$ - time period of using equipment (year), (OC) - entry price, Op - cumulative depreciation, $(\mathrm{Nc})$ - total costs, $\left(\mathrm{N}_{\mathrm{pr}}\right)$ - average costs, $\mathrm{t}_{\mathrm{opt}}-$ optimal time period.

\section{Results and discussion}

The economic efficiency of biomass boilers depends on the level of operating costs and therefore it is important to analyze the risks that can arise in the use of biomass boilers. This research was realized in 5 small enterprises that used biomass boiler for preparation of energy. Operating costs of these machines were rising in each enterprise. This equipment was analyzed in time of their usage. The main goal of this research was minimizing of the operating costs. In the first step were collected data for the model of renovation. All indicators operating costs, enter price, depreciations were calculated to average values (Table 2.). Entry price (OC) for biomass boiler is $5284 €$.

Table 2. Basic parameters of biomass boiler

\begin{tabular}{|c|c|c|c|c|c|c|}
\hline $\begin{array}{c}\text { Time period } \\
\text { (t) }\end{array}$ & 1 & 2 & 3 & 4 & 5 & 6 \\
\hline $\begin{array}{c}\text { Depreciation } \\
\text { (O) }\end{array}$ & 440 & 440 & 440 & 440 & 440 & 440 \\
\hline $\begin{array}{c}\text { Residual price } \\
\text { (ZC) }\end{array}$ & 4844 & 4403 & 3963 & 3523 & 3082 & 2642 \\
\hline $\begin{array}{c}\text { Operating } \\
\text { costs (Np) }\end{array}$ & 0 & 75 & 80 & 85 & 90 & 500 \\
\hline
\end{tabular}

\begin{tabular}{|c|c|c|c|c|c|c|}
\hline $\begin{array}{c}\text { Time period } \\
\text { (t) }\end{array}$ & 7 & 8 & 9 & 10 & 11 & 12 \\
\hline $\begin{array}{c}\text { Depreciation } \\
(\mathbf{O})\end{array}$ & 440 & 440 & 440 & 440 & 440 & 440 \\
\hline $\begin{array}{c}\text { Residual price } \\
\text { (ZC) }\end{array}$ & 2202 & 1761 & 1321 & 881 & 440 & 0 \\
\hline $\begin{array}{c}\text { Operating } \\
\text { costs (Np) }\end{array}$ & 60 & 65 & 70 & 75 & 80 & 500 \\
\hline
\end{tabular}

Source: own source by formula 1-5

By the model of renovation of the biomass boiler, it was simulated the optimal time for renovation by formula 1-5 presented in Table 3. Average entry price was $5284 €$ and recommended technical life time of equipment was 12 years. Depreciation is given by technical assumption - 12 years that means technical durability of production equipment. In the research was applied the method of straight line depreciation. The model of renovation was applicable in 5 year of usage. The enterprises had a plan of technical evaluation of equipment in the 6th year and in the 12th year of usage. In this time there were planed financial sources of $500 €$ for technical changes. From the 7 th year to the 11 year of usage of equipment were simulated the operating costs. From the data of operative evidence, we have found out that operating costs in every year of its using are continually increasing. Depreciated price is stated according to the depreciation plan for production equipment - biomass boiler for 12 years by law of taxes in Slovakia. All the information we have obtained from accounting evidence and we started to solve the problem of renovation biomass boiler during life cycle of equipment. 
Table 3. Calculation of optimal time of biomass boiler

\begin{tabular}{|c|c|c|c|c|c|c|}
\hline $\begin{array}{l}\text { Time period } \\
\text { (t) }\end{array}$ & 1 & 2 & 3 & 4 & 5 & 6 \\
\hline $\begin{array}{l}\text { Cumulative } \\
\text { operating } \\
\text { costs (NP) }\end{array}$ & 0 & 75 & 155 & 240 & 330 & 830 \\
\hline $\begin{array}{l}\text { Cumulative } \\
\text { depreciation } \\
\text { (Op) }\end{array}$ & 440 & 880 & 1321 & 1761 & 2201 & 2642 \\
\hline $\begin{array}{l}\text { Total costs } \\
\text { (Nc) }\end{array}$ & 440 & 955 & 1476 & 2001 & 2531 & 3472 \\
\hline $\begin{array}{l}\text { Average } \\
\text { total costs } \\
\text { (Npr) }\end{array}$ & 440 & 478 & 492 & 500 & 506 & 579 \\
\hline $\begin{array}{l}\text { Time period } \\
\text { (t) }\end{array}$ & 7 & 8 & 9 & 10 & 11 & 12 \\
\hline $\begin{array}{l}\text { Cumulative } \\
\text { operating } \\
\text { costs }\left(\mathrm{N}_{\mathrm{P}}\right) \\
\end{array}$ & 890 & 955 & 1025 & 1100 & 1180 & 1680 \\
\hline $\begin{array}{l}\text { Cumulative } \\
\text { depreciation } \\
\text { (Op) }\end{array}$ & 3082 & 3522 & 3963 & 4403 & 4843 & 5284 \\
\hline $\begin{array}{l}\text { Total costs } \\
\text { (Nc) }\end{array}$ & 3972 & 4477 & 4988 & 5503 & 6023 & 6964 \\
\hline $\begin{array}{l}\text { Average } \\
\text { total costs } \\
\left(\mathrm{N}_{\mathrm{pr}}\right) \\
\end{array}$ & 567 & 560 & 554 & 550 & 548 & 580 \\
\hline
\end{tabular}

Source: own source

From the calculation, it results that optimal time for renewal of production equipment should be after 11 years of its service, since value of cost function is minimal in this year and after 11 years' service the cost starts to increase. The goal of the management is to decrease operating cost for production equipment and therefore management must decide how to renew production equipment biomass boiler or to buy new equipment for biomass. Such Access of model solving for optimization is showing to the time interval of renewal, but it does not follow up the way of production equipment renovation, and it is its disadvantage.

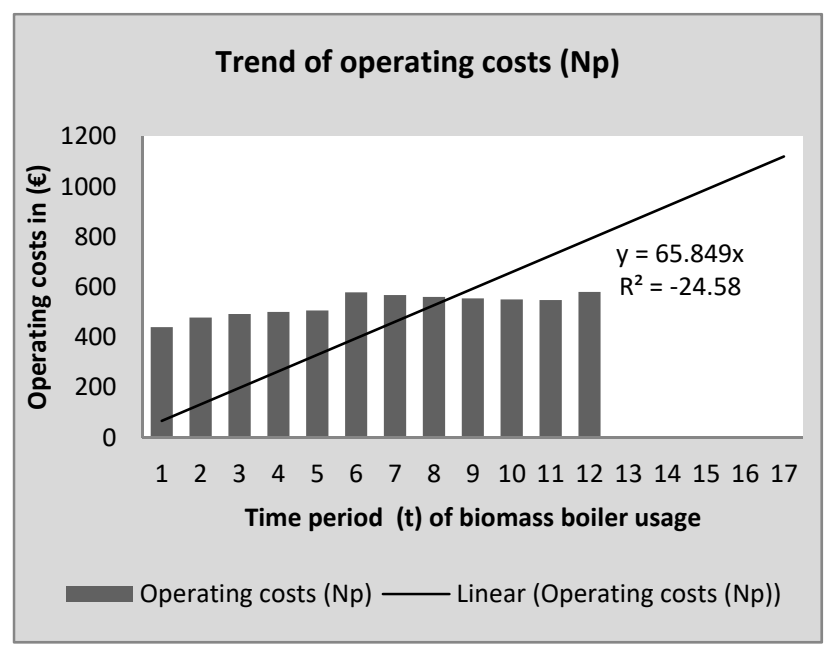

Figure 3. Biomass boiler optimal time Source: own source
For enterprises it is necessary to make renovation after 11 years of production equipment usage. From the 11th year of using biomass boiler will be increasing operating costs according fig.4. Linear function shows progressive trend of operating cost in the future. This fact means innovation of biomass boiler or its change. When firm enough financial means for extended reproduction has and when firm decides to invest money for buying new equipment, it will be one of the possibilities how to decrease operating cost for the equipment. The other problem of buying new biomass boiler are financial sources because the value on the market is on level $5500 €$ $15600 €$. Operating costs for 5 years in the future have an increasing tendency. This fact draws the attention of enterprises to solving the problem of renewing the biomass boiler equipment or to the investment plan for the new equipment. In conclusion, it can be stated that companies have two basic options for the renewal of a biomass boiler - the renewal of equipment or the purchase of new equipment. They can also significantly affect the value of costs by changing the depreciation method, introducing preventive maintenance, replacing biomass boiler components and regular care of the equipment. In this way, they can extend the life of the boiler and use it in the future. In general, extending the life of equipment increases costs because more equipment failures occur. With this model, the company can control the condition of the equipment, the development of costs, and the development of failures and ultimately influence the

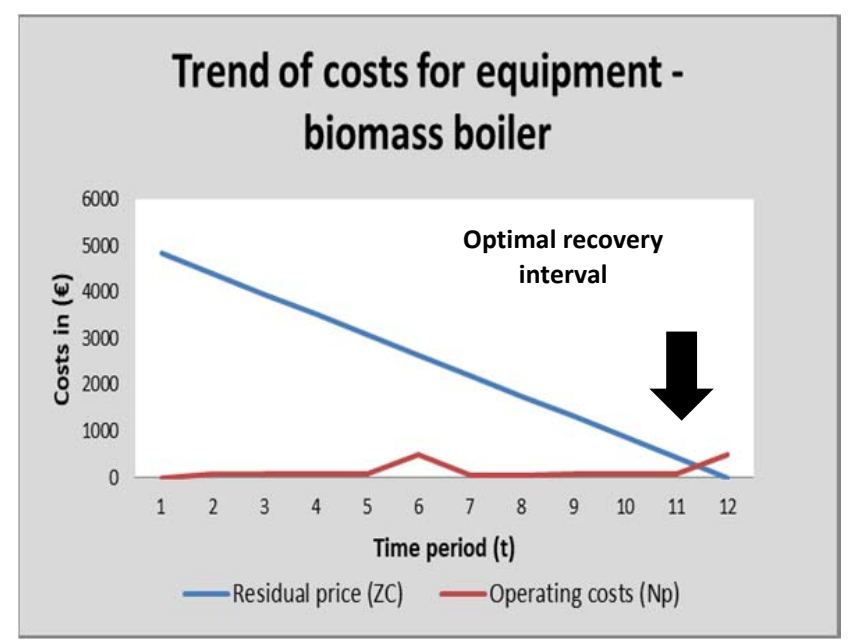

financial side - operating costs.

Figure 4. Trend of development of operating costs Source: own source

\section{Conclusion}

The possible alternative solution for biomass boiler is direct combustion of biomass material agricultural waste, woody materials. In this paper we solved problem with biomass boiler and its use 
during the life cycle of the equipment. We used of quantitative model of operating research - model of renovation of equipment. This model of renovation can be used for various types of equipment and it is very easy for mathematical calculation. This model needs entry information about equipment for example entry price, method of depreciation, operating costs and plan of technical evaluation. All those information are in internal documentation by the Law of accounting in Slovakia. Model of renovation creates instrument for management and planning of renovation of equipment. Renovation needs financial sources, and it is very important for small enterprises to plan financial sources because the value of biomass boiler is $5500 €-15600 €$ on the market.

The results of model of renovation represent the optimal time of renovation biomass boiler in the 11th year of its operating life. In this year the operating costs were $548 €$ and it was minimal limit of costs. Average total costs are moving from $440 €$ to $580 €$. Costs were increased step by step into the 6th year of using biomass boiler and then was documented a decrease since the 6 th year into the 11th year. The reason of decreasing costs was the implemented new system of maintenance. The benefit of this model was the decrease of operating costs for about $140 €$ that they influence profit creation and renovation of biomass boiler that will be used in the future. This solution requires implementing preventive maintenance and care of equipment for biomass boiler. This optimizing model can be adapted for each firm and to simulate development of operating costs in care of machines and equipment. Care of machines and equipment is a basic condition for their functionality and usage in production processes.

\section{Acknowledgements}

This contribution is part of project KEGA 049TUKE-4/2019 and VEGA 1/0651/2018.

\section{References}

[1]. Schiffauerova, A., \& Thomson, V. (2006). A review of research on cost of quality models and best practices. The International Journal of Quality \& Reliability Management, 23(6), 647.

[2]. Diamantopoulos, A., Fritz, W., \& Hildebrandt, L. (Eds.). (2013). Quantitative Marketing and Marketing Management: Marketing Models and Methods in Theory and Practice. Springer Science \& Business Media.

[3]. Zhou, A., Xu, H., Tu, Y., Zhao, F., Zheng, Z., \& Yang, W. (2019). Numerical investigation of the effect of air supply and oxygen enrichment on the biomass combustion in the grate boiler. Applied Thermal Engineering, 156, 550-561.
[4]. Simionescu, C. S., Barda, A. M., \& Diaconescu, O. R. (2017, August). Operating Optimization of the Equipment and Machines Using Imposed Lifespan Between Maintenance. In 2017 Fourth International Conference on Mathematics and Computers in Sciences and in Industry (MCSI) (pp. 98-101). IEEE.

[5]. Więcek, D., Więcek, D., \& Dulina, L. (2020). Materials requirement planning with the use of activity based costing. Management Systems in Production Engineering, 28(1), 3-8.

[6]. Bastian, E., \& Muchlish, M. (2012). Perceived environment uncertainty, business strategy, performance measurement systems and organizational performance. Procedia-Social and Behavioral Sciences, 65(3), 787-792.

[7]. Hrablik Chovanová, H., \& Babčanová, D. (2014). Meaning of quantitative methods in managerial decision making. Časopis výzkumu a aplikací v profesionální bezpečnosti, 7(2-3).

[8]. Shukla, H., Chhadva, J., Arora, J., Sheth, K., \& Malhotra, K. (2017). Application of operation research in logistics and warehouse optimization. International Journal of Innovative Research in Technology \& Science, 5(5), 1-7.

[9]. I.Gros. (2003). Quantitative methods in management decision. Praha: Grada Publishing, 2003. ISBN 80247-0421-8

[10]. Šebo, J., Kádárová, J., \& Malega, P. (2019, October). Barriers and motives experienced by manufacturing companies in implementing circular economy initiatives: The case of manufacturing industry in Slovakia. In 2019 International Council on Technologies of Environmental Protection (ICTEP) (pp. 226-229). IEEE.

[11]. J.Skřivánek. (2005). Quantitative methods of financial operations. Iura Edition: Bratislava, p.248.

[12]. Čulková, K., Kudelas, D. \& Weiss, E. (2014). Effectiveness of investment to renewable energy sources in Slovakia. Acta Montanistica Slovaca, 19(2), 65-69.

[13]. Teplická, K. (2008). Using of the quantitative methods in reproduction process of fixed capital of the firm. Výrobné inžinierstvo, 63-64.

[14]. Zgodavova, K., Kisela, M., \& Sutoova, A. (2016). Intelligent approaches for an organisation's management system change. The TQM Journal, 28(5), 760-773.

[15]. M. Abolhasanpour, A.M. Kimiagari, A. Abolhasanpoor, M. Tajalli, V. Shokouh .(2019). Modeling an integrated multi-distributor supply chain with production mean. IJMBE journal, 6(2), 63-71.

[16]. Beer, M., Rybár, R., \& Kal'avský, M. (2018). Renewable energy sources as an attractive element of industrial tourism. Current Issues in Tourism, 21(18), 2139-2151.

[17]. Gabriel, M., Tschandl, M., \& Posch, A. (2014). Sustainability-oriented lifecycle costing. Annals of the Faculty of Engineering Hunedoara, 12(1), 33.

[18]. Ostrowski, P., Maj, I., Kalisz, S., \& Polok, M. (2017). Biomass low-temperature gasification in a rotary reactor prior to cofiring of syngas in power boilers. Applied Thermal Engineering, 118, 785-795. 
[19]. P. Tauš et.al. (2017). Renewable energy sources on the world energy market and Slovakia. Čeněk: Plzeň, 2017, p.112.

[20]. Tauš, P., Taušová, M., Šlosár, D., Jeňo, M., \& Koščo, J. (2015). Optimization of energy consumption and cost effectiveness of modular buildings by using renewable energy sources. Acta Montanistica Slovaca, 20(3), 200-208.

[21]. Senthiil, P. V., Sirusshti, V. A., \& Sathish, T. (2019). Artificial intelligence based green manufacturability quantification of a unit production process. International Journal of Mechanical and Production Engineering Research and Development, 9(2), 841-852.
[22]. Markulik, Š., Cehlár, M., \& Kozel, R. (2018). Process approach in the mining conditions. Acta Montanistica Slovaca, 23(1).

[23]. Š. Valenčík, J. Kováč. (2009). Moddelling, quantification and strategy of renewal machine. Transfer inovácií, 14, 204-207.

[24]. Sütöová, A., \& Segiňáková, S. (2018). Improving Information Flow for Decision Making on Product Quality in the Automotive Industry. Quality Innovation Prosperity/Kvalita Inovácia Prosperita, 22(1).

[25]. Ivaničová, Z., Brezina, I., \& Pekár, J. (2002). Operačný výskum. Bratislava. Ekonómia. 